\title{
KLASIFIKÁCIA ALOKAČNÝCH MODELOV ZARIADENÍ PRE POTREBY VÝSTAVBY A OPTIMALIZÁCIE DISTRIBUČNÝCH SIETÍ.
}

\author{
Daniel Zeman*¹, Radovan Madleňák*2
}

\section{Úvod}

S distribučnými siet'ami prichádzame do kontaktu vo sfére súkromného aj verejného sektora. Jedná sa bud' o rôzne obchodné ret'azce väčšieho či menšieho druhu, ako aj zasielatel'ské siete a iné prepravné siete, ktorých účelom je prepravit' tovar resp. produkty od jedného zariadenia k druhému, poprípade ku koncovému zákazníkovi. V konečnom dôsledku môžeme nazvat' distribučnými siet’ami aj siete, prostredníctvom ktorých sa prenášajú informácie a dáta, napr. internet, alebo telekomunikačné siete.

Pre potreby výstavby a organizácie takýchto novovybudovaných sietí, ako aj následnej optimalizácie týchto sietí, alebo optimalizácie už existujúcich starších sietí sa využívajú alokačné modely. Dané modely nachádzajú uplatnenie aj pri siet’ach, ktorých účelom nie je prenos produktov, resp. informácií, a to napríklad pri výstavbe sietí zdravotníckych zariadení, pri lokalizácii skládok s nebezpečnými odpadmi a pod..

\section{Použitie alokačných modelov}

Alokačný model predstavuje vo všeobecnosti zjednodušený matematický model, ktorého aplikáciou si môžeme odpovedat' na nasledujúce otázky:

- Kol'ko zariadení by malo byt' umiestnených na sieti?

Dáva odpoved' na exaktný počet potrebných zariadení, tak aby boli pokryté všetky požiadavky, a nedošlo tak k situácii, kedy by bol nedostatok potrebných zariadení, alebo naopak nadbytok, a dochádzalo by tak k plytvaniu dostupných kapacít.

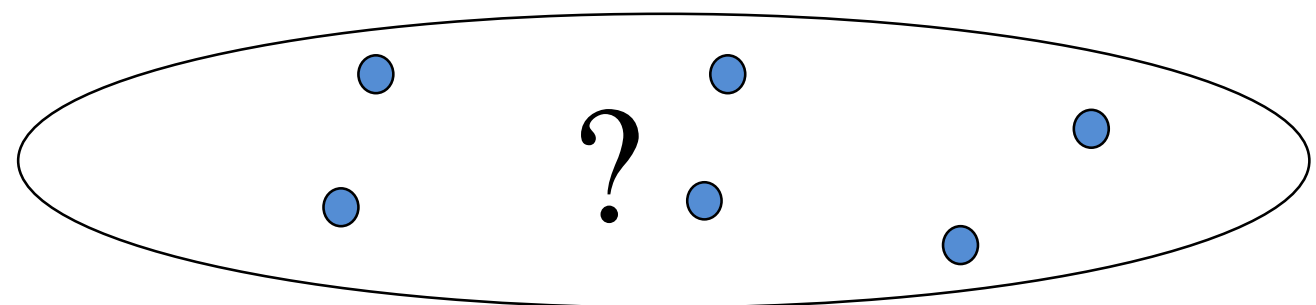

Obr. č. 1. Počet zariadení v sieti.

\footnotetext{
1 * Ing. Daniel Zeman, Žilinská univerzita v Žiline, Fakulta prevádzky a ekonomiky dopravy a spojov, katedra spojov, Univerzitná 1, 01026 Žilina, e-mail: daniel.zeman@fpedas.uniza.sk

2 *doc. Ing. Radovan Madleňák, PhD., Žilinská univerzita v Žiline, Fakulta prevádzky a ekonomiky dopravy a spojov, katedra spojov, Univerzitná 1, 01026 Žilina, e-mail: radovan.madlenak@fpedas.uniza.sk
} 
- Kde je potrebné dané zariadenia umiestnit?

Zaoberá sa rozmiestnením jednotlivých zariadení v priestore, kde najčastejšie narába s rôznymi metrickými jednotkami predstavujúcimi vzdialenost' medzi jednotlivými zariadeniami. Je potrebné brat' do úvahy, aby boli pritom pokryté všetky požiadavky danej oblasti a nedochádzalo na druhej strane k zbytočnej koncentrácii zariadení v oblastiach kde to nie je potrebné.

V inom prípade môže vytvárat' vopred definovanú hierarchickú štruktúru jednotlivých zariadení s vyjadrením vzájomného vzt’ahu nadradenosti a podradenosti.

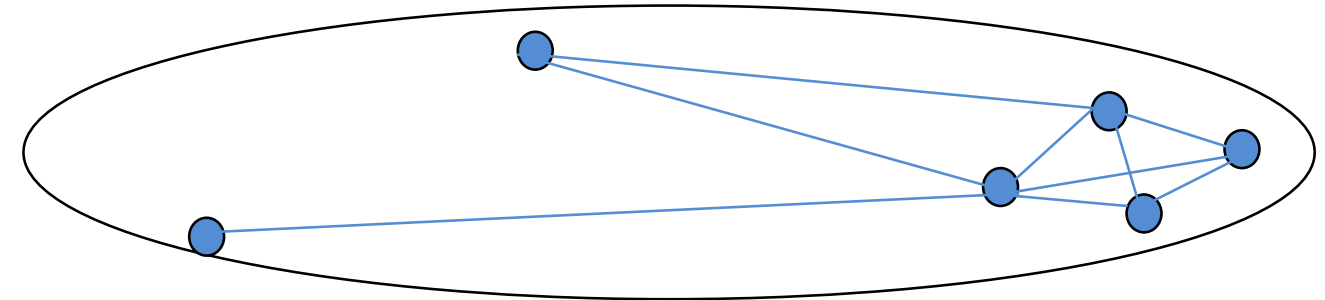

Obr. č. 2. Umiestnenie zariadení v sieti.

- Akú vel'kú oblast' by mali tieto zariadenia obsluhovat'?

Predstavuje takzvaný dosah jedného zariadenia umiestneného $\mathrm{v}$ určitom bode siete. Môže sa nazývat' aj akčným rádiom, a môže byt' závislý od vzdialenosti, poprípade kapacity lokalizovaného zariadenia.

Vo všeobecnosti sa kladie dôraz na rovnomerné rozčlenenie, tak aby nevznikali výrazne disproporčné rozdiely medzi jednotlivými pokrytými oblast’ami.

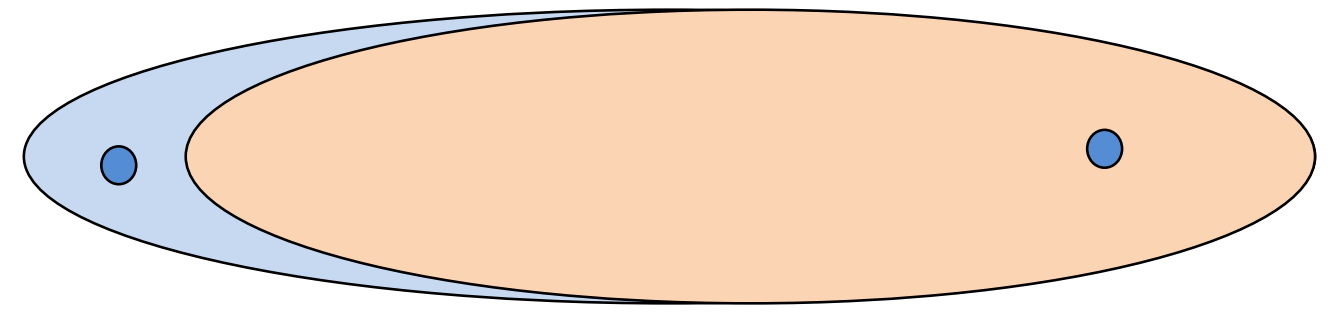

Obr. č. 3. Akčný rádius jednotlivých zariadení v sieti.

- Aké vel'ké by mali byt' jednotlivé zariadenia?

Riešením tejto otázky získame prehl'ad o potrebnej kapacite daného lokalizovaného zariadenia, t.j. kol'ko produktov, dát, zásielok je schopné prijat', na dobu nevyhnutného spracovania uskladnit' a následné expedovat' d’alej, a zároveň tým dostaneme aj údaje o nákladoch potrebných na zabezpečenie takéhoto zariadenia.

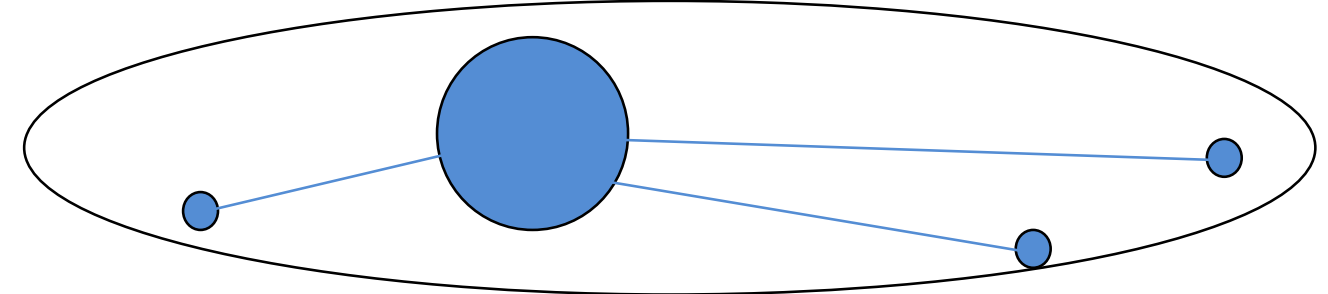

Obr. č. 4. Vel'kost' jednotlivých zariadení v sieti. 
Odpovede na tieto otázky závisia v hlavnej miere na súvislostiach, z pohl’adu ktorých je daný alokačný problém posudzovaný, a taktiež na prvkoch a objektoch na ktorých je založený. Výsledkom toho všetkého je nájdenie takej situácie, kedy je možné vyhodnotit' riešenie vzniknutého problému ako najvhodnejšie v daných súčasných podmienkach.

\section{Klasifikácia alokačných matematických modelov}

$\mathrm{Na}$ základe spoločných znakov, poprípade podobného použitia môžeme alokačné modely zariadení rozdelit' do troch nasledujúcich skupín, pričom každá z nich obsahuje viacero konkrétnych modelov.

1. Nepretržité alokačné modely (z anglického continuous location models, ináč nazývané aj models in the plane).

2. Siet'ové alokačné modely ( $\mathrm{z}$ anglického network location models).

3. Zmiešané celočíselné programové modely ( $\mathrm{z}$ anglického mixed - integer programming models).

- nekapacitné jednostupňové modely (uncapacitated single - stage models),

- kapacitné jednostupňové modely (capacited single - stage models),

- viacstupňové modely (multi - stage models),

- viac produktové modely (multi - product models),

- dynamické modely (dynamic models),

- pravdepodobnostné modely (probabilistic models),

- hub alokačné modely (hub location models),

- alokačné modely založené na okružných jazdách (routing location models),

- alokačné modely s viacnásobným ciel'om (multi - objective location models)[1].

\section{Nepretržité alokačné modely}

Tieto modely je možné charakterizovat' na základe dvoch vlastností:

- priestor $\mathrm{v}$ ktorom riešime daný alokačný problém je neprerušený, nepretržitý a to znamená, že je možné alokovat' zariadenie v ktoromkol'vek bode v rovine,

- vzdialenost' je meraná prostredníctvom vhodných metrických jednotiek, typicky v sústave manhattan alebo euklidovskej sústave.

Úlohou takto konštruovaných alokačných modelov je nájst' koordináty množstva „p“ zariadení v priestore s ohl'adom na minimalizáciu celkovej vzdialenosti medzi lokalizovaným zariadením a miestom vyžadujúcim požiadavky zariadenia.

Najjednoduchší model sa zvykne nazývat' aj Weberov model.

\section{Siet'ové alokačné modely}

V siet'ových alokačných modeloch sú vzdialenosti vyčíslené na základe najkratšej vzdialenosti $\mathrm{v}$ grafe, pričom $\mathrm{v}$ tomto grafe uzly predstavujú požiadavky vrcholov a potenciálna siet' zariadení je tvorená podmnožinou uzlov pospájaných vzájomne hranami.

Najznámejším siet’ovým alokačným modelom je tzv. p - median alokačný model, ktorý definoval v roku 1964 S. Louis Hakimi, pričom vychádzal z vylepšeného Weberovho modelu. Neskôr sa ukázalo, že formuláciou tohto modelu sa položili základy pre tvorbu iných deterministických, statických a nekapacitných modelov využívajúcich účelovú funkciu „minisum“. 
Všeobecne je p - median alokačný model určený na nájdenie polohy „p“ zariadení v sieti so zretel’om na minimalizáciu priemerných nákladov spojených sich obsluhou, a taktiež minimalizáciou požadovaných hodnôt vzdialeností medzi požiadavkami vrcholu a zariadením, ku ktorému sú priradené.

Nemenej známym alokačným modelom patriacim do tejto skupiny modelov je $\mathrm{p}-$ center alokačný model, aplikáciou ktorého sa snažíme minimalizovat’ akčný rádius tak, aby každá požiadavka vrcholu bola pokrytá v rámci vnútorne stanovenej vzdialenosti jedným zo zariadení. Zjednodušene to môžeme vyjadrit', že v danom modeli ide o minimalizáciu maximálnej vzdialenosti medzi požiadavkou vrcholu a najbližším zariadením k tomuto vrcholu - minimax[3].

V rámci jednotlivých modelov je teda možné rozpoznat' dva typy účelových funkcií, ktoré požadujeme od daného modelu, a to: minisum a minimax. Minisum modely sú vytvorené za účelom minimalizácie priemerných vzdialeností medzi umiestňovanými zariadeniami, na druhej strane minimax modely sú určené pre minimalizáciu maximálnych vzdialeností medzi týmito zariadeniami. Zatial čo minisum modely riešia predovšetkým alokačné problémy súkromných spoločností, tak minimax modely nachádzajú väčšie uplatnenie pri riešení takýchto problémov vyskytujúcich sa vo sfére verejného sektora.

\section{Zmiešané celočíselné programové alokačné modely}

Vychádzajúc z vopred stanovenej množiny miest (uzlov), do ktorej môžu byt' alokované požadované zariadenia, vel'a alokačných problémov je možné modelovat' prostredníctvom zmiešaných celočíselných programových alokačných modelov.

Tieto alokačné modely sa len mierne odlišujú od siet'ových alokačných modelov. Zatial' čo siet'ové alokačné modely jasne znázorňujú štruktúru množiny potenciálnych zariadení a ich vzájomných metrických vzdialeností, tak na druhej strane programové alokačné modely len jednoducho využívajú vstupné údaje a parametre, bez potreby vediet' odkial' tieto údaje pochádzajú.

Skupinu týchto alokačných modelov je možné rozčlenit' na niekol'ko rôznych druhov alokačných modelov, vychádzajúc pritom z účelu ich použitia a dostupných údajov:

Kapacitné a nekapacitné alokačné modely - nekapacitné modely nie sú ovplyvňované obmedzujúcimi požiadavkami plynúcimi z polohy umiestňovaného zariadenia. Ak je kapacita nevyhnutnou požiadavkou potenciálneho miesta umiestnenia nového zariadenia, potom je nutné umiestňovat' toto zariadenie s maximálnou opatrnost'ou. Pre potreby naplnenia týchto kapacitných podmienok sa môže v neskoršej dobe vyhodnotit', či budú tieto kapacity doplńané z jednotlivých alebo viacnásobných zdrojov.

Jednoúrovňové a viacúrovňové alokačné modely - jednoúrovňové modely sa zameriavajú na distribučné systémy zabezpečujúce pokrytie práve jednej úrovne. Naopak viacúrovňové modely sú určené na vyhodnocovanie toku produktov prechádzajúceho niekol'kými hierarchicky usporiadanými úrovňami.

Jedno produktové a viac produktové alokačné modely - jedno produktové modely sú charakterizované skutočnost'ou, že požiadavky, cena a dostupné kapacity niekol'kých produktov môžu byt' zoskupené do jedného rovnorodého produktu. V prípade ak sa produkt aj nad'alej javí ako nehomogénny, je vhodné analyzovat' štruktúru zvoleného distribučného systému prostredníctvom viac produktových modelov.

Statické a dynamické alokačné modely - úlohou statických modelov je optimalizovat' výkon celkového systému za účelom jednej reprezentatívnej periódy, ktorá by takto predstavovala určitý pohl'ad na systém. To je vkontraste s dynamickými modelmi zobrazujúcimi údaje (cena, požiadavky, kapacity, atd'.), ktoré sa neustále menia včase, a ktoré nám umožňujú takto vytvorit’ dlhodobejší plán v horizonte udalostí. 
Deterministické a pravdepodobnostné modely - vo všeobecnosti vstup do modelu, resp. jeho štruktúra, pôvod a dôveryhodnost', nie sú vždy známe s istotou. Údaje sú dost' často založené na predpovediach, odhadoch a podobných nie vel'mi presných postupoch, čo prináša so sebou vždy určitý stupeň neistoty o konečnom výsledku použitého modelu. Na základe toho je možné rozlíšit' deterministické modely, kedy predpokladáme, že vstupný tok dát a ich štruktúra sú známe s istotou, alebo pravdepodobnostné modely, ak vstupný tok dát je predmetom neistoty a je možné o ňom pochybovat'[1].

\section{Záver}

Použitie vhodného alokačného modelu pri výstavbe novej siete, či pri optimalizácii už stávajúcej je vždy v konečnom dôsledku závislé od účelu na aký je daná siet’ projektovaná. Každý z vyššie uvedených modelov prináša pre svojho riešitel'a určité výhody ale zároveň aj nevýhody, ktorých výsledok je možné vidiet' prostredníctvom rôznych simulácií a dosiahnutých výsledkov.

Snahou riešitel'a by tak vždy malo byt' dosiahnutie optimálneho riešenia, ktoré by predstavovalo konečnú podobu projektovanej siete, bez potreby d’alších optimalizácií, a s tým spojenými výdavkami v podobe l'udských a materiálových zdrojov.

\section{Literatúra}

[1] DREXL, A., KLOSE, A.: Facility location models for distribution system design, In: European Journal of Operational Research 162 (2005) 4 - 29, Dostupné na: www.sciencedirect.com

[2] MADLEŇÁK, R. 2005. Algoritmy vhodné pre optimalizáciu najvyššej úrovne poštovej prepravnej siete. In: Doprava a Spoje [online], 1, Dostupné na: $<$ http://fpedas.uniza.sk/dopravaaspoje/rok.php?rok=2005\&c $=1>$.

[3] ZEMAN, D.: Konštrukcia prepravnej siete alternatívneho poštového operátora, diplomová práca, Katedra spojov, Žilinská univerzita v Žiline, 2009 